\title{
Disease and Health Care in the North-West of Spain in the Early Modern Period. The Bierzo Region
}

\author{
María José Pérez Álvarez
}

The Bierzo is one of the natural districts of the Spanish Province of Leon. Situated in the western part of this province, it borders the Galician

1 Provinces of Lugo and Orense to the west; to the south lies another natural region of Leon, the Cabrera; to the east stand the Mounts of Leon; while to the northwest there is the former administrative district of Ribas del Sil de Arriba. This is a territory with considerable geographic diversity, in which it is possible to distinguish mountainous zones, occupying somewhat more than half of the district, the so-called Upper Bierzo; plains or depressions, forming the Lower Bierzo; and transitional areas, linking these two.

The chief administrative centre of the Bierzo was and is the town of Ponferrada, although other places such as Villafranca del Bierzo or Cacabelos also were of importance during the early modern period. In the case of the first of these, this was because of its religious standing, which developed under the auspices of the marquises of Villafranca, while in the case of the second it was thanks to the major fairs held there.

\section{The Hospital Network of the Bierzo}

The Bierzo was crossed by the Pilgrim's Way to Santiago de Compostela, which ran into it from the city of Astorga in three branches that join up at Ponferrada. One crossed the Mounts of Leon by the Manzanal pass, another via the pass of Foncebadón and the third was termed the Cerezal route ${ }^{1}$. The branch with the greatest traffic was the second. For this reason, during the Middle Ages it had a greater concentration of activities aimed at assisting pilgrims. Thus, at several places along this

1 Cavero Domínguez, G. (1987), Peregrinos e indigentes en el Bierzo Medieval (siglos XIXVI). Hospitales en el Camino de Santiago, Ponferrada: Basílica de la Encina y Asociación de Amigos del Camino de Santiago, pp. 43-52. 
route, such as Manjarín, El Acebo or Molinaseca, hospitals or hostels were set up, intended to help travellers. This does not imply that centres of this kind were not in existence on the other routes, of course. Once the three branches united, pilgrims could find places to stay or be treated for ailments at Ponferrada, Camponaraya, Cacabelos, Villafranca or Pereje. The life of some of these establishments was ephemeral. However, a few of them did remain open throughout the Early Modern Period.

In those centuries, although the Pilgrim's Way had already lost the exclusively religious character with which it had originated, it continued to be a heavily used route $^{2}$. At that time the main flow of travellers were no longer pilgrims but voyagers of every social class and with very varied purposes for their journeys ${ }^{3}$. Nonetheless, not all were potential clients of these establishments lying along the Way. Only those who had no money were accepted, since anybody who could afford to stay the night in more comfortable lodgings was not allowed to have recourse to the charity offered by these foundations. However, all travellers were exposed to the risk of catching an illness, so that many of the hostels, which had a hospital section, included in their regulations the possibility of helping wealthier patients, as long as they paid for the costs of treatment and convalescence.

According to the general responses to the survey by the Marquis de la Ensenada, undertaken during the 1750s, there were already no more than four such centres offering aid and assistance. In Bembibre there was the Saint John Hospital, which took in sick pilgrims and travellers, having for this purpose an annual income of 242 reals [the "real" was a small silver coin, worth somewhat less than the contemporary English shilling]. There was a more modest institution at Columbrianos, maintained with the cash that came from two ground rents (38 reals) and the income in kind from lands it owned (26.5 cuartales [about five bushels] of wheat). Larger establishments were to be found in Villafranca del Bierzo and Ponferrada, these having a hospital section. The Saint James Hospital in Villafranca had 10 beds to care for the sick and for pilgrims. It was maintained from an income of 3,000 reals derived from various estates and ground rents. Here, 10 cuartos a day were spent on the food ration for each sick person admitted [the cuarto was a copper coin, worth rather less than a contemporary English halfpenny]. Pilgrims, on the other hand, were given only a bed, fuel and salt. The Ponferrada establishment was stated to have a more modest income, 600 reals. Nonetheless, the expenditure on food was more generous, a whole real per patient per day. The respondents to the

2 On the true function of the Pilgrim's Way in the Middle Ages and Modern Period, see Ofelia Rey Castelao, O. (2006), Los mitos del apóstol Santiago, Vigo: Nigratea.

3 In early modern times this route lost in part its religious status, to become a route for beggars, as it became to some extent a "poor man's way", travelled by people who lived off the alms distributed by the hostels. See Carasa Soto, P. (1991), Historia de la beneficencia en Castilla y León. Poder y pobreza en la sociedad castellana, Valladolid: University of Valladolid, p. 31. 
survey declared that this income was not sufficient to cover the costs arising. However, the income recorded for this hospital must have been either considerably understated or the outcome of some short-term cash flow difficulty. This impression is confirmed by looking at the outlays on food during the 1760s, which totalled 2,500 reals. In fact, one century earlier the hospital had had annual receipts of an amount similar to this.

\section{Hostels and Hospitals in Ponferrada}

Of the eight establishments that were active during the Middle Ages in the town of Ponferrada, only the one known as the Queen's Hospital was still operational in the eighteenth century. Alongside this welfare institution there was one other with very specific functions: the foundlings' home that cared for abandoned children.

The establishment run by the Pomboeza guild had disappeared because this religious brotherhood had been broken up in the sixteenth century. For the same reason, and at about the same time, the Saint Nicholas Hospital had ceased operations. It is unsure at what exact point the Old Saint Lazarus Hospital went out of existence, but there is a record of New Saint Lazarus being merged with the Queen's Hospital in $1661^{4}$. Before the end of the Middle Ages, this latter had also absorbed the Pedro Didaci Hospital. For its part, after a brief lifespan, the establishment that had been founded by the Lords of Priaranza as an annexe to the Convent of the Conception was closed down in the last quarter of the sixteenth century. Little can be said about Saint John's, founded in the thirteenth century, or Saint Martin's, which in the mid-sixteenth century was run by the hermits who were dedicated to the Saint in question ${ }^{5}$.

For its part, at the end of the 1820s, at the urging of the Bishop of Astorga, Don Leonardo Santander y Villavicencio, the Queen's Hospital had annexed to it the Ponferrada religious guilds of Our Lady of the Oak, Saint Joseph, Saint Barbara, the Angel, Saint Nicholas and Saint Crispin. The motive for this amalgamation must be seen, on the one hand, as influenced by the policy of limiting this type of religious association that had been adopted by the Crown and, on the other, as the result of the declining number of members and the shrinkage in their resources. Their income was necessary to maintain the Queen's Hospital, especially after the early nineteenth century. In 1805 the hospital lost a lawsuit against the Monastery of Carracedo concerning lands that constituted one of its main sources of revenue. From that moment onwards, its income was reduced to around 1,300 reals a year ${ }^{6}$.

4 A.H.M.P. (Ponferrada Municipal Historical Archive), Folder No. 27.

5 For more information, see Cavero Domínguez, G. (19878), Peregrinos e indigentes en el Bierzo Medieval (siglos XI-XVI), pp. 71-78.

6 A.H.M.P. Folder No. 25, File 11. 
During the Middle Ages in Spain, the term hospital was used to designate all establishments that had been set up with a clear charitable purpose of aiding the needy, whether or not they offered medical care. This usage continued into the Modern Period $^{7}$. For example, Don Andrés Pérez de Capillas called the establishment he founded at Puente Villarente in 1537 a hospital, while in reality it was no more than a hostel for pilgrims and travellers. In the case of the Queen's Hospital, this hostel function was paralleled by medical and health assistance, besides another purpose fundamental in those days: spiritual aid, valued by the sick as highly as physical assistance ${ }^{8}$. Likewise, during the whole period the centre did not lose sight of the mediaeval ideal that considered aid to the poor as a way of gaining spiritual salvation for all those involved in hospital work. Indeed, the Bishops of Astorga, during all their visits to the institution of which records have survived, reminded the administrators that they should keep in mind that the poor represent the figure of Christ ${ }^{9}$.

The Queen's Hospital was founded by the Catholic Monarchs in 1498, or more accurately re-founded, since, although new installations were set up in the Parish of Saint Andrew, it appears that they arose from the merging of other centres of this kind. Hence, it fell within the framework of the policy put forward by the Monarchs, who were seeking to create a network of hospitals characterized by effi-

7 Although some humanist thinkers, like Luis Vives, reminded monarchs of the responsibility that the Civil Power had to take on when secularizing these centres, in practice they remained strongly linked to the Church, as had been the case in the mediaeval period. In any case, these projects of the humanists faded away during the seventeenth century. This change in attitude arose from the financial troubles affecting the State's revenues and the atmosphere of the Counter-Reformation, in which aid to the needy once again became a crucial part of the exercise of charity. Once again in the eighteenth century civil responsibility came to prevail over religious charity when it was a question of offering assistance to those in need. Despite the disagreements arising in the eighteenth century between conservatives, who preferred traditional charity, and innovators, and in spite of the efforts of Charles III to secularize welfare, neither at this period nor in those immediately following were there any major advances in this direction. See García Guerra, D. (1983), El hospital Real de Santiago (1499-1804), Corunna: Barrie de la Maza Foundation, pp. 48-49 and 138; Callahan, W. (1978), "Caridad, sociedad y economía en el siglo XVIII", Moneda y Crédito, 146, pp. 65-77; Schubert, A. (1984), "Nuevos enfoques sobre la beneficencia en España en el siglo XIX”, Studia Zamorensia, 19, pp. 325-336. Carasa Soto, P. (1991), Historia de la beneficencia en Castilla y León, pp. 9-16.

8 Religious consolation at this time was valued as much as medical treatments, which were often subordinate to it. See Henderson, J. (2001) "Healing the Body and Saving the Soul: Hospitals in Renaissance Florence. Renaissance Studies", Journal of the Society for Renaissance Studies, 15 (2), pp. 188-216. Valenzuela Candelario, J. (2002), "Hospitales y Beneficencia. Historias de hospitales". Revista de Trabajo Social y Salud, 43, pp.39-66.

9 Even in establishments that were not dependent on the Church, bishops had the right to carry out inspection visits. See Carmona García, J.I. (1979), El sistema de la hospitalidad pública en la Sevilla del Antiguo Régimen, Seville: Seville Provincial Council, p. 19. 
ciency and not by a plethora of small and poorly endowed centres ${ }^{10}$. From its earliest moments, it was managed by the Town Council, although it seems that there may also have been a guild linked to the centre ${ }^{11}$. Such a group is mentioned in the document by which the Monarchs Isabella and Ferdinand conceded a juro [a perpetual annuity from the public purse] to the hospital. However, there was no longer any mention of it in the regulations drawn up at the end of the eighteenth century. Be that as it may, the most significant fact is that the Queen's Hospital was the only charitable centre of any size operating in the Province of Leon that was not directly managed by the Church ${ }^{12}$.

The work of the hospital was not limited to medical and health care for patients admitted to it. It also gave alms to the poor, generally in the form of a dole of food, provided beds for pilgrims and travellers, and carried out transfers. These involved transporting by horse to the next stage in their journey those patients who had now recovered, or who showed signs of being on the mend, sometimes giving them in addition a small sum of money so that they could buy food for themselves for the next few days ${ }^{13}$. The number of charitable actions of this kind was not very large, since the years for which data are available show a variation between 4 in 1661 and 15 in the previous year. Alongside these more normal sorts of aid, the hospital could also offer extraordinary assistance, as in the instance arising in 1686 when the centre paid for a wet-nurse for a baby girl abandoned there ${ }^{14}$.

Very little information is available about the building that housed the Queen's Hospital. It is known only that it had at least two wards for the sick, one for each sex, with various other sections, among them a kitchen, a chapel and rooms for the

10 This process of unification of hospitals initiated by the Catholic Monarchs was continued by the Hapsburg kings who followed them on the throne of Spain. The consequences are seen not only in the Province of Leon, but from the dawn of the Modern Period can be noted throughout Spain. For example, for Pamplona, see Ramos Martínez, J. (1989), La salud pública y el Hospital General de la ciudad de Pamplona en el Antiguo Régimen (1700 a 1815), Pamplona: Regional Government of Navarre, p. 191.

11 The Monarchs ordered the council, magistrates, councillors, officials and good citizens of the town of Ponferrada, and the guild members who were or might be associated with the said hospital to take care to visit and inspect the hospital. "El hospital de Nuestra señora de Santa María de la Villa de Ponferrada", Estudios Bercianos, 13, 1990, p. 44.

12 On the network of hostels and hospitals in the Province of Leon, see Martín García, A. and Pérez Álvarez, M. J., (2007), "Hospitalidad y asistencia en la provincia de León a finales del Antiguo Régimen (1728-1896)", Dynamis, 27, pp. 157-185.

13 An entry records an outlay of 3 reals to discharge a poor man from the hospital, plus two day's food for the journey, in total 4.5 reals. A.H.M.P.

14 Thus, it was fulfilling the mission that had been entrusted to it by the Catholic Monarchs when they assigned to it an income drawn from the land called "Cabañas de Fabero", so that the poor pilgrims who passed through the town would have a place to stay and a bed to sleep in and so that food might be purchased for any patients who might be admitted to the hospital. "El hospital de Nuestra señora de Santa María de la Villa de Ponferrada", Estudios Bercianos, 13, 1990, p. 43. 
staff. It also had an entrance hall, access to which was through a door in a stone façade on which a religious image was set. Immediately next to the building there was a cemetery, reserved exclusively for the centre, and inaugurated in $1564^{15}$.

At the end of the eighteenth century, the building underwent some renovation work, which continued in the following century. Specifically, in 1798 a cistern was constructed underneath the room of the senior nursing officer, being intended to hold collected rainwater. Such a tank was very necessary for hygiene in the hospital, as the centre was a long way from the river and it had proved impossible to dig a well. However, this repair work does not seem to have been all that was needed, since in the minute book for 1799 it was noted that the women's ward was close to collapse and that the kitchen was poorly ventilated. To right these problems, the authorities controlling the centre decided to commission a renovation project from a builder. Although the work could have been paid for from the hospital's existing funds, they agreed to nominate a person to go and seek contributions from the surrounding villages. The argument they put forward for this decision was that the inhabitants of all these places would be those who benefited most from the aid provided by the centre.

Despite these projects, deficiencies continued over the next few years. In 1801 sources record the problems relating to the women's ward, because of its limited capacity, inappropriate orientation and the unpleasant odours that were noticeable in it, leading to more than a few infections. This unacceptable situation led the board of the centre to hasten a petition for permission to build, sent to the Council of Castile. Once again, these projects came to nothing, with the defects already pointed out remaining unremedied. In any case, it is not strange that these plans for restoration work could not be put into effect, if it is taken into account that the crisis of the beginning of the eighteenth century more or less ran on into the Peninsular War. In fact, between 1808 and 1816, the establishment stayed closed because of the damage that had been done to it by the occupying French troops.

\section{Governance and Internal Organization of the Hospital.}

As has already been noted, the Queen's Hospital was managed by the Town Council. During the seventeenth century and most of the eighteenth, it exercised its direction through one or two councillors. The financial side of management fell to the steward or administrator, to whom all the other workers at the hospital reported. The hospital had a fairly small staff to attend to the $\operatorname{sick}^{16}$ : physician ${ }^{17}$,

15 González García, M. “Notas para la historia de Ponferrada”, Bierzo, 1977, pp. 98-104, pp. 98-99.

16 The composition of the hospital's staff is very similar to what was in place in the hospital at Loja, even though this had a larger capacity for patients, specifically 24 beds. See 
blood-letter (later replaced by a surgeon), chaplain and "attendant". This latter post, as has been observed elsewhere in the Province, seems in fact to have been held by a married couple, even though the accounts record only a single salary, as for instance in the contract drawn up in $1655^{18}$. This couple shared the domestic, maintenance and basic nursing tasks in accordance with their sex. This simple organizational arrangement became considerably more complex at the end of the eighteenth century ${ }^{19}$. From this point onwards, after the establishment of new regulations, it is possible not merely to know the composition of the board of management of the hospital, but even the specific tasks entrusted to each of the members composing it.

The new rules set down that the Queen's Hospital was to be managed by a board made up of nine members, who gave their services free. This group comprised the Corregidor [Royal Alderman, an official appointed by the Crown to preside over the town council] of the town, who held the chair, and another eight lay and ecclesiastical members who had the right to speak and vote: the longest-serving town councillor, the priests of the Parishes of Our Lady of the Oak and of Saint Andrew, the hospital chaplain, the contador principal [head finance officer], the procurador sindico general [town ombudsman] and a gentlemen of the town who was to be somebody well known for his virtue and charity towards the poor. The term of office is not specified in the regulations, and so would appear to have depended on the civil or ecclesiastical post held outside the hospital. The frequency of meetings was set down in the rules, however. Once a month there was to be an ordinary meeting, while extraordinary meetings were to be called whenever any member requested one. Both were to be held at the Town Hall. This board of management was to be responsible for taking all decisions affecting the centre. It was only when problems arose which needed an immediate solution that the chair-holder had the power to act alone.

Once the board had been constituted, holders were nominated for thirteen posts. Of these, five (the secretary and four commissioners) were chosen from among the

Coronas Tejada, L. (1990), El hospital Real de Nuestra Señora de la Misericordia de Loja, Granada: University of Granada, pp. 46 et seqq.

17 The fact that in one way or another medical cover was provided for all social classes implied a certain socialization of medicine. It should be remembered that only the wealthiest could afford to have private treatment from a university-qualified practitioner. See García Guerra, D. (1983), El hospital Real de Santiago... p. 58-59, and (1978), "La asistencia hospitalaria en la España Moderna: el Hospital Real de Santiago”, Estudios de Historia Social, 7, pp. 289-327.

18 González García, M. "Notas para la historia de Ponferrada, p. 99.

19 The process of drawing up the new regulations was approved in 1788, but had begun in the previous year. They were produced by Don Jerónimo Francisco de Acevedo, who used as a model a set that had been provided by the Council of Castile, with the intention that the deplorable state and poor administration of income of the centre in Ponferrada should be remedied. A.H.M.P. Folder 26, Vol. 3. 
board members. Two of these commissioners were charged with the management of the pasture land belonging to the centre, one oversaw the dispensary and the fourth was responsible for charity. The remaining eight positions were more directly related to the hospital: chaplain, steward, physician, surgeon, dispensary officer, the praticante [roughly equivalent to a houseman or senior nursing officer, being a man with basic medical and surgical training], nursing sister and porter. The 1788 regulations in fact implied an increase in the hospital's staff with respect to the previous situation. Up till then, attention to the physical needs of patients had been provided by a much smaller staff, composed of two practitioners (physician and surgeon) and an attendant, while the chaplain had taken care of spiritual needs. Above this small group was the steward, responsible for managing the centre's property.

The secretary had to keep the hospital's minute book up to date, issue, with the chair-holder's approval, the orders for payment of salaries and bills for supplies and give notice of meetings. For their part, the commissioners for charity and for the dispensary acted as supervisors. The dispensary officer had to report to the second of these, who was responsible for inspecting the dispensary so as to ensure that it was supplied with all the preparations necessary to cover the needs of the hospital and meet demands from outpatients. At the moment when the new rules were drawn up, it would appear that the dispensary had been much neglected, so that great stress was laid on the necessity for it to be restored in order for it to regain its former good reputation throughout the Province. The dispensary officer could be aided by an assistant who was to be trained so as to cover for any absence of the officer himself. The commissioner for charity was to keep an eye on the conduct of those employees directly linked to hospital assistance. He was required for this purpose to visit the centre three times a week, so as to ensure for himself that the patients were being properly looked after.

The chaplain was responsible as much for physical assistance to patients, in collaboration with other employees, as for their spiritual care. Hence, this post was considered to have the greatest and most continuous workload. Among the work assigned were the tasks of visiting the patients frequently, consoling them, administering the sacraments to them, helping them to die well if their ailment took a fatal turn, and of burying the dead in the graveyard. Moreover, the chaplain was required to celebrate mass on days of obligation and holidays. The important part played by this employee in the establishment is reflected in the prominence of his post in the regulations. These stipulate that he should not be permitted to leave the town for more than a week at a time. Similarly, to ensure that the post was filled, the Bishop of Astorga was requested to allot it a Church income of 2,200 reals, which implied a doubling of the pay hitherto received. Such an interest in laying down the pay and obligations of the chaplain is all the more significant when the 
Figure 1. Governance and Internal Organization of the Hospital.

BOARD OF MANAGEMENT

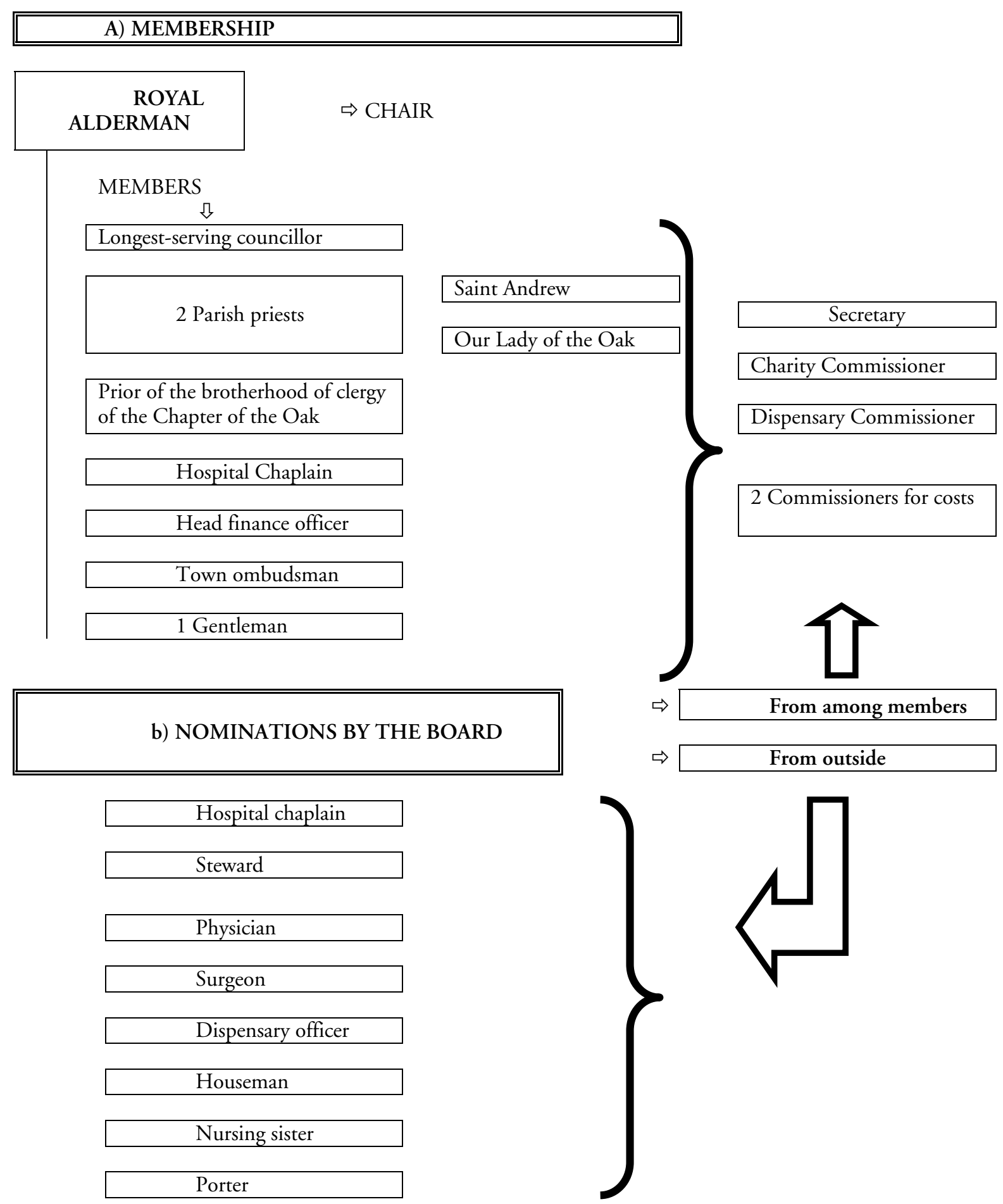

For their part, the two "commissioners for costs" had the obligation of ensuring that the maximum financial benefit was obtained from the pasture land owned by the hospital.

same is not done for the physician. That is to say, even in the Age of Enlightenment it would appear that spiritual interests of mediaeval origin predominated over 
medical and health services. This state of affairs is even more striking if it is kept in mind how closely the establishment was linked with the civil authorities.

The regulations allotted the porter a very minor role. Initially, he was required merely to let members know when meetings were being held, to light the brazier warming the room where they were to take place, and stay at the door while the discussions lasted. As time went by, the post was assigned more tasks, and the number of such workers was even increased to two. In 1801, when the centre was overwhelmed with requests for help because of the difficult circumstances the country was going through in that decade, one porter was given the specific job of providing food to travellers, while preventing them from taking refuge in the hospital.

Finally, one crucial position was that of steward. It was not for nothing that the responsibilities that this person took on were recompensed with the largest salary among the lay staff: 2,200 reals per year. This was considerably higher than the physician (550) or the surgeon $(300)^{20}$. The steward managed all the hospital's financial resources, under the direct supervision of the head finance officer. He was also charged with implementing all the decisions taken by the board of management in this area. The post was involved with the most varied matters, from representing the centre in lawsuits, defending the hospital's interests, to checking on what kind of firewood was being used, from purchasing food for the larder to selling the clothes of inmates who died. The fact that all the finances of the hospital were in his hands was the reason that the regulations stipulated clearly a monetary guarantee that would avoid possible fraud and aid in selecting in all cases an individual with ample financial resources. Thus, those aspiring to this post were required to deposit caution money of 1,000 ducats [equivalent to some five times the yearly pay or more].

Although the norms approved in 1788 appeared to regulate adequately the internal organization of the hospital, it was not long at all before they began to be disobeyed. Just a few years after the new regulations came into force, the minute book began to be kept, and this has scattered throughout it notes referring to failures to obey the rules. For example, the physicians and surgeons kept patients in the hospital longer than necessary; the priest was not fulfilling his temporal and spiritual obligations; or the dispensary officer was not attending to the store of drugs in a professional way. The reaction of the board to such irregularities was quite prompt, except in the case of the priest, since he was under the jurisdiction of the bishop, who was the only person who had the capacity to dismiss him.

Hospital treatment was available only to the clearly destitute who did not have chronic diseases, as the long process of medical attention such cases required would

20 Nonetheless, this information should be nuanced, as the practitioners were the same men as were appointed to similar posts for the town. This means they were not full-time. 
restrict the number of other patients who could be handled ${ }^{21}$. On this point, in 1791 the board agreed that if this rule was broken, besides expelling such patients, it would require the outlays involved by their convalescence to be borne by the physician and surgeon ${ }^{22}$. If these prior requisites were met, the centre's practitioners (the physician and surgeon) were responsible for deciding if patients should be admitted. If they felt they should be, they submitted a report to the board for approval so that the sick person could be brought into the hospital. Once this had happened, a full operating procedure was brought into play, in which all the hospital's employees were direct participants, all with their own specific competences. The first thing to be done by patients was to hand over their clothing to the chaplain, who would take care of it while they remained in the hospital. If any patients died, their clothes were given to the steward, who with the board's agreement would use them as seemed most appropriate or sell them ${ }^{23}$.

The sick were visited twice a day by the physician and surgeon, accompanied by the chaplain, the nursing sister and the houseman. These last two had the mission of correctly applying all the prescriptions of the doctors with regard to diet and medicine. The nursing sister did so in the women's ward, while the houseman looked after the men's ward, both of them providing a continuous presence. They also had to take care of the daily chores in the hospital, such as keeping the wards and equipment clean, or ensuring that the food for patients was properly prepared and in good condition. In addition, the nursing sister had charge of the kitchen and of the laundry service, for which she could call on the help of another person. For his part, the houseman was responsible for the care of all the hospital's equipment, whether it was bedding, furniture or other items, which were issued to him against an inventory. He was also expected to have some knowledge of surgery so as to be able to offer initial treatments in the case of any emergency. So as to ensure that these staff were completely dedicated to caring for the patients, they were required to live in the hospital, where they were given a daily food ration identical to that served to the patients.

21 This sort of limitation on the admission of patients was also to be found in other hospitals, for example at Saint James of Compostella. See García Guerra, D. (1983), El hospital Real de Santiago... p.52.

22 In April 1799, after the monthly visit carried out by the commissioner, he informed the board that there were in the hospital two sick people whose ailments had become chronic. In consequence, it was agreed that the commissioner should seek the best way of getting rid of them, even at some cost to the centre, although in such a way that this discharge would be consistent with the patients' right to charity and brotherly treatment. A.H.M.P., Folder 26.

23 This was a common practice in establishments of this kind. In this instance it is not known what weight this sort of income had in the revenues of the centre as a whole. See González Díaz, A. M. (1997), Poder urbano y asistencia social: el hospital de San Hermenegildo de Sevilla (1453-1837), Seville: Seville Provincial Council, p. 212. 
The chaplain's participation in visits was motivated by his double task of being an intermediary between the nursing personnel and the doctors and of supervising the well-being of the patients. He was supposed to guarantee that the people most directly involved in their treatment were scrupulous in fulfilling their duties.

Treatment for the poor was free. Nevertheless, if any of them had some property and died in the hospital, the steward was responsible for taking the necessary steps to offset the costs that such patients had made necessary during their sickness against the value of the property in question ${ }^{24}$.

\section{The Financial Support for the Hospital}

The Queen's Hospital was a small centre with a modest endowment, and this naturally had an influence over its beneficent actions, limiting the amount of assistance it could offer. During the second half of the seventeenth century there were few years in which its income reached as much as 3,000 reals (Table 1). This precarious state of affairs was not just a result of the harsh negative climate of that century, but was also due to the sparse resources with which the centre had been endowed.

At the end of the sixteenth century its revenue came fundamentally from two sources: a perpetual annuity and the donations made weekly by the richer and chief citizens of the town. In 1661, the Town Council of Ponferrada, conscious of the limitations and difficulties faced by the Queen's Hospital in treating the sick, added to this the income of the inactive Hospital of Saint Lazarus ${ }^{25}$. This new endowment had the effect of increasing revenue by some $12 \%$ to $13 \%$, as can be seen from a breakdown of the accounts for the period 1662 to 1664 . To this small financial boost donations and charitable offerings were gradually added, as was the interest derived from loans made. In this way, little by little a small financial holding was built up that allowed the hospital to cover its needs.

24 Such practices led Ramos Martínez to feel that the deaths of patients were more profitable for the hospital than their restoration to health. Ramos Martínez, J. (1989), La salud pública y el Hospital General, p. 234.

25 The magistrates and councillors of Ponferrada, as patrons of the Hospital of Saint Lazarus in this town, recognizing the restricted income of the Queen's Hospital of Ponferrada, which led to a lack of aid for the poor who came to it, and recognizing that there were no longer any patients at the Hospital of Saint Lazarus, added the revenues of this latter hospital to those of the infirmary of this town. A.H.M.P., Folder 26. 
Table 1. Income and Expenditure of Queen's Hospital (1662-1721).

\begin{tabular}{crcrc}
\hline Year & Income in reals & Average Yearly Income & Expenditure & Out-turn \\
\hline $\mathbf{1 6 6 2}$ & $2,054.4$ & $2,054.4$ & $1,578.6$ & 475.8 \\
$\mathbf{1 6 6 3}$ & $2,054.4$ & $2,054.4$ & $2,447.7$ & -393.3 \\
$\mathbf{1 6 6 4}$ & $2,062.0$ & $2,062.0$ & $2,220.3$ & -158.3 \\
$\mathbf{1 6 7 6}$ to 1679 & $10,843.5$ & $2,710.9$ & $10,906.0$ & -62.5 \\
$\mathbf{1 6 8 7}$ to 1689 & $9,569.0$ & $3,189.7$ & $9,016.0$ & 553.0 \\
$\mathbf{1 6 9 3}$ to 1698 & $17,253.0$ & $2,875.5$ & $16,724.0$ & 529.0 \\
$\mathbf{1 6 9 9}$ & $3,401.0$ & $3,401.0$ & $2,874.0$ & 527.0 \\
$\mathbf{1 7 0 0}$ & $2,271.0$ & $2,271.0$ & $2,159.0$ & 112.0 \\
$\mathbf{1 7 0 1}$ & $2,341.0$ & $2,341.0$ & $1,970.0$ & 371.0 \\
$\mathbf{1 7 0 2}$ & $2,935.0$ & $2,935,0$ & $2,461.0$ & 474.0 \\
$\mathbf{1 7 2 1}$ & $1,667.0$ & $1,667.0$ & $1,524.0$ & 143.0 \\
\hline
\end{tabular}

Source: Account ledgers

The way in which the Queen's Hospital's accounts were kept, sometimes in a very summary form and sometimes grouped by the period in office of a steward, it is hard to undertake any detailed survey of the sources of income. Nonetheless, consideration of a small sample for which a year-on-year breakdown was carried out with some precision makes it possible to get a feel for where revenues were drawn from by the centre (Table 2). Of these, those derived from investment in censos [a form of ground rent or interest on a real estate loan] were the most prominent. Thereafter came the income from rural properties, with in third place the revenue from the juro or perpetual annuity, at this time paid out of the alcabalas ${ }^{26}$ of the town of Ponferrada and its surrounding district, which had been a donation from Isabella the Catholic Monarch in 1499, drawn from the property known as the preserved lands of Cabañas de Fabero ${ }^{27}$.

In the second category, that is, revenue coming from rural properties, one striking item is the forty fanegas ${ }^{28}$ of grain [around sixty bushels] paid to the hospital by the nearby Monastery of Carracedo. The contribution in question represented between $50 \%$ and $60 \%$ of the total amount received under this heading ${ }^{29}$. The extensive property of the Cabañas de Fabero led the hospital into a long lawsuit, lasting more than three centuries, against this monastery. The final judgement,

26 These alcabalas were a form of purchase or consumption tax.

27 This perpetual annuity was initially intended to be charged to the pastures and haymeadows of the preserved lands of Cabañas de Fabero. However, by 1566 it was already being drawn from the rates of the town of Ponferrada, and throughout the seventeenth and early eighteenth century it was derived from the alcabalas of the town and its district. A.H.M.P. Folder 27.

28 The fanega was a measure of capacity used at this time, and it amounted to between 40 and 45 kilograms of grain.

29 The payment of this amount of grain was subject to an agreement concluded in 1569 between the Monastery of Carracedo and the Hospital. See Balboa, J. A. "El hospital de la Reina de Ponferrada”, Bierzo, 1977, pp.45-55, p. 49. 
delivered in the first few years of the nineteenth century, went against the hospital $^{30}$. With respect to charitable donations or alms, it was only in 1702 that they were of any significance in percentage terms. This was when the substantial sum of 440 reals was received, coming from a legacy bequeathed by Doña Antonia Gamarra, a resident of Ponferrada. Similar bequests were made at other times, but involved much more modest amounts that seldom made any impact on the total income received.

Table 2. Breakdown of the Income of the Queen's Hospital in Reals.

\begin{tabular}{cccccc}
\hline & Ground Rents & Dividends \& Interest & Annuity & Charitable Donations & Total \\
\hline 1676 & 1.418 & 955 & 206 & 30 & 2.609 \\
$\%$ & 54.4 & 36.6 & 7.9 & 1.1 & 100 \\
1686 & 1.092 & 563 & 206 & - & 1.861 \\
$\%$ & 58.7 & 30.3 & 11.1 & - & 100 \\
1702 & 1.261 & 1028 & 206 & 440 & 2.935 \\
$\%$ & 43.0 & 35.0 & 7.0 & 15.0 & 100 \\
1721 & 792 & 785 & 90 & - & 1.667 \\
$\%$ & 47.5 & 47.1 & 5.4 & - & 100 \\
\hline
\end{tabular}

Source: Account Ledgers.

Some knowledge of the main financial blunders made by the administrators and health personnel can be gleaned from the information derived from inspection visits that is included in the account books. Details of one such visit are available for the sixteenth century, relating to 1566 , and of two in the seventeenth century, one inspection being held in 1682 and another in 1687. While the first was carried out by the town's Corregidor or Royal Alderman, for the remaining two it was the chief religious authority in the diocese, the Bishop of Astorga, who made the inspection. This change in the activity of supervision of the hospital to ecclesiastical overseers, in place of civil, is clearly related to the provisions of the Council of Trent, which granted bishops the right of visitation for all such centres ${ }^{31}$.

In 1682, no reference of any sort was made to financial matters, which leads to the assumption that the stewards had been fulfilling their duties meticulously. The same was not true of 1687, when the bishop criticized those responsible for finances

30 On 7 May 1805 the minute book recorded the loss of this suit, stating that the sentence would bring extreme ruin to the town and its surroundings, as troops that were continually moving between Castile and Galicia, pilgrims going to Saint James of Compostella and Galicians travelling to work on the harvest all relied on the aid of this hospital to treat their ailments. It also noted that the private gentleman Don Antonio Rueda (a member of the board) moved by charity and zeal, volunteered to go to the capital at his own expense to beg the King to overthrow the verdict, or, if this were not feasible, to assign to the hospital income from funds intended for pious works or hospitals, of which there were many unused in the villages and religious guilds of the Province. A.H.M.P., Folder 26.

31 See González Dáz, A. M. (1997), Poder urbano y asistencia social: el hospital de San Hermenegildo de Sevilla (1453-1837), Seville: Seville Provincial Council, p. 61. 
for not keeping proper accounts over the previous few years. In consequence, they were given a month in which to sort out this unacceptable situation, failing which they would be excommunicated. Poor management would seem to have been a frequent problem in the centre. However, it was in the 1560s and at the end of the eighteenth century that it reached its greatest proportions.

On 13 January 1566 the Corregidor of Ponferrada, Master Fernando de Robles, recorded that the centre's limited funds were being eaten away because of the poor administration of resources. Don Fernando noted that the amount of 7,000 maravedis [when initially awarded, equivalent to some 2,300 reals] with which the centre had been endowed by Queen Isabella for the use and profit of the hospital and the poor admitted to it, and which constituted the principal source of income at that time, was not being collected. Similarly, the negligence of the stewards had led to the loss of some properties of the hospital and the income from a legacy bequeathed by one Francisco Arias, a resident in the town. Furthermore, the necessary care was not being given to the noting down of the donations made each week by the richer individuals in the town, which led to a fear that this custom might be discontinued. Such unforgivable negligence not only had a negative effect on the hospital's finances; it also had a clear impact on the treatment available for the sick poor. To put an end to this calamitous situation, orders were given during the visit that henceforward an inventory should be kept of all property and goods and caution money required from the stewards to guarantee against losses through bad management. Somewhat more than two centuries after these incidents, in 1787, a similar situation arose, since one of the chief reasons justifying the need to draw up new regulations was the deplorable state and poor administration of the revenues of the hospital.

With regard to the distribution of costs for the hospital, similar information is available to that already noted for income. From this, it becomes evident that the two largest expenditures were those on food for patients ${ }^{32}$ and on pay for staff. Together, these accounted for somewhat more than $50 \%$ of all outlays and in 1662 , 1663 and 1664 represented more than $75 \%$ of costs (Table 3). The percentage spent on food was very variable, being dependent on the number of people treated. Thus, for instance, during the last quarter of 1677 the hospital had no admissions. In contrast, with regard to pay a certain stability is observable, since between 1676 and 1702 variations in it were minimal.

32 The high percentage of outlays represented by food for patients would appear to be common in other centres, too. See García Hourcade, J. J. (1996), Beneficencia y sanidad en el S. XVIII. El hospital de San Juan de Dios de Murcia, Murcia: University of Murcia, p. 117. 
Table 3. Expenditure of the Queen's Hospital (1662-1721).

\begin{tabular}{ccccccc}
\hline Year & Outgoings & Food & Pay & \% Food & \% Pay & Total \% Food plus Pay \\
\hline 1662 & $1,578.6$ & 800.7 & 610 & 50.7 & 38.6 & 89.4 \\
1663 & $2,447.7$ & $1,398.8$ & 596 & 57.1 & 24.3 & 81.5 \\
1664 & $2,220.3$ & $1,166.1$ & 596 & 52.5 & 26.8 & 79.4 \\
$1676-1679$ & $10,906.0$ & $2,836.0$ & 2,780 & 26.0 & 25.5 & 51.5 \\
$1687-1689$ & $9,016.0$ & $2,831.0$ & 2,145 & 31.4 & 23.8 & 55.2 \\
$1693-698$ & $16,724.0$ & $4,935.0$ & 4,302 & 29.5 & 25.7 & 55.2 \\
$1699^{33}$ & $2,874.0$ & $1,566.0$ & - & 54.5 & - & - \\
1700 & $2,159.0$ & $1,027.0$ & - & 47.6 & - & - \\
1701 & $1,970.0$ & 638.0 & - & 32.4 & - & - \\
1702 & $2,461.0$ & 697.0 & 750 & 28.3 & 30.5 & 58.8 \\
1721 & $1,667.0$ & 317.0 & 739 & 19.0 & 44.3 & 63.3 \\
\hline
\end{tabular}

Source: Account Ledgers.

The remaining headings under which money was spent are highly varied: firewood, soap, candles, medicines, transferring patients, religious celebrations, equipment for the hospital, repairs, and the like. It was precisely these last two, the replacement of furniture, linens and other items to accommodate the sick and repairs to the hospital and the chapel of Saint Lazarus, that became more prominent in the last quarter of the seventeenth century and in 1702. So, for instance, between 1687 and 1689 what are termed new works in the hospital were undertaken. They must have consisted fundamentally of renovations to the wards, the reinforcement of a wall and repairs to the entrance, involving an outlay of 2,044.7 reals. At this same time purchases were made, to the value of 263.7 reals, of blankets, sheets and bedspreads. A few years later, in 1697, work was carried out on the façade of the hospital. Then again, in 1702, repairs were effected to the roof of Saint Lazarus, at a cost of 340 reals, while a further 198 went on replacing bed linen. All this was possible thanks to the slight increase in revenue.

With respect to the buying of medicines, another of the main expenditures, it is only in a very few years that this is distinguished from general costs. However, data referring to a series of years permit it to be calculated that such purchases must have amounted to between $2 \%$ and $3.5 \%$ of annual outlays ${ }^{34}$. It is unknown what kind of drugs were in use, since entries are very general, normally appearing in the books as simply payments for medicine for the dispensary.

33 In 1699, 1700 and 1701, the entries for expenditures are divided into just two: food and other.

34 The calculations refer to 1687,1688 and from 1693 to 1698. 


\section{Buildings and Food}

As has already been pointed out, the Ponferrada hospital was a modest establishment, this being reflected in its installations. At the end of the seventeenth century, it had just eight beds for the sick poor of both sexes. It was only in the case of particular urgency, such as an epidemic of some contagious disease or a natural catastrophe, that the board of management might agree to an expansion in the hospital's capacity for patients. In any case, such an increase was always limited, generally amounting to no more than a couple of extra beds ${ }^{35}$.

This situation of penury noted at the end of the eighteenth century was inherited from previous periods, despite the efforts made throughout that time to improve installations. According to the 1566 inventory $^{36}$, the furnishings of the centre comprised a bench, a chair, a large chest, two trestles, an iron lamp and eleven wooden beds. In the kitchen there was a large pot or cauldron and a fire crane ${ }^{37}$. With regard to bed linen, there were fourteen sheets, four mattresses, two pillows (one old, one new) and twenty-four blankets made of frieze. This, plus one hoe, constituted all the equipment the centre had. Three years later, bar slight changes in the number of sheets and blankets, everything was the same.

At the end of the 1670s, thanks to the modest funds which had gradually been built up, and the merger with the Hospital of Saint Lazarus, the installations were somewhat better equipped. The largest purchase of material took place between 1676 and 1678. At that time the centre owned two chests, three benches, a writing desk and ten wooden beds (five of them new), besides a modest amount of kitchenware. The supply of linen had also been considerably expanded, and two pictures with religious motifs had even been hung on the walls, one showing the Apostle Saint James, the other an Ecce Homo. These improvements did not last long. In fact, ten years later, in 1687, the Bishop of Astorga during a visitation put on record the parlous state in which the bed linen was, this causing the sick poor to be untidy and unprotected against the cold. For this reason he ordered these problems to be solved by the purchase of new items.

Inspection visitors were quite strict (if the mentality of the period is taken into account) in respect of everything relating to the cleanliness of the installations and the way the sick were treated. There are repeated recommendations in respect of

35 In November 1803 the minute book recorded a decision that not more than eight patients should be in the hospital at any one time, unless it was a grave emergency, such as had occurred in previous months as a consequence of the large number of tertian and quartan agues that had been suffered by the inhabitants of the town and its district. In a situation of that kind, it was agreed that the number of beds could be raised to ten, this measure being communicated to the physician and surgeon by the secretary to the board of management. A.H.M.P., Folder 26.

36 The inventories are included in the account books. A.H.M.P. Libros de cuentas del Hospital de la Reina [Accounts of the Queen's Hospital].

37 A fire crane is a device used to hang a pot over a fire. 
keeping the patients, the bedding and the wards clean. The documents also put some stress on recalling that a destitute person represents Christ. For this reason, the staff were to be kind to the patients. Beside this humane treatment, it was absolutely necessary to respect the timetable for meals and for medication, as also, in the case of the practitioners, to make the appropriate visits to examine the patients.

A major feature of hospitals like the Queen's, dealing primarily with the indigent, was the food provided for the sick, since for many of them it represented a therapeutic item of considerable importance for their recovery. It should not be forgotten that quite often the ailment itself was not the trigger for the parlous physical state of patients. It was rather the case that other factors, such as hunger or exhaustion from travelling, that led to their admittance.

The data found in the sources with regard to patients' diets are mostly concentrated in the last few years of the eighteenth century. Even so, there are some very interesting references relating to earlier centuries. It is known that in the late seventeenth and early eighteenth centuries the hospital kitchen prepared a "poor man's stew", a dish composed primarily of chickpeas and belly pork, flavoured with a little saffron and other spices. The greater part of these basic products was purchased by the institution at the start of the year. Thus, during the 1690s, it was usually in January that the administrators bought a small quantity of belly pork, likely to have been salted, weighing between nine and twelve kilograms, together with a similar quantity of chickpeas. The remaining products were replaced as and when they ran out.

Besides basic foodstuffs, the institution's books from the late seventeenth and early eighteenth centuries also mention the purchase of mutton, honey, sugar, eggs, milk, cake, bread, wine and spirits. Apart from the first of these, such purchases were mostly occasional ${ }^{38}$ and in response to very specific needs. All the same, with regard to bread and wine, the fact that no large amounts were spent on buying them was a consequence of the fact that it was more or less self-sufficient, thanks to the income in kind that it enjoyed.

By the middle of the eighteenth century, the documentation is rather more detailed with respect to the diet fed to the sick. Between 1765 and 1769 it is known that the daily ration provided to patients included about 400 grams of bread, accompanied by beef or mutton, and wine. Alongside these foodstuffs, the consumption of eggs became more general. At this period, patients consumed an egg

38 For instance, in the case of honey, just a half litre was bought in 1694, in the month of December, and in 1699 a single litre was purchased. In March 1696 the outlay on cake, sugar, eggs and spices amounted to only 5 reals. 
every two or three days. The purchase of cake, sugar and chocolate ${ }^{39}$ became more usual, although it must be surmised that, as in other establishments, these products were intended for special diets.

There is more detail in the monthly summaries of the food consumed in the year 1800. The daily allowances for the sick (which would appear to have included the "poor man's stew") consisted of approximately 362 grams of meat, 453 of bread, 45 of belly pork, 68 grams of chickpeas and 0.8 of a gram of lard, topped off with a daily quarter-litre of wine. This basic allocation was complemented with the products already noted in the documentation from the previous century (cake, chocolate, chestnuts, milk or sugar ${ }^{40}$ ) or with other new foods, such as rice. In contrast, the consumption of eggs, frequent in earlier years, became only occasional ${ }^{41}$. In this list, fish is missing, this being an essential food in Lent and on fast days, which is mentioned in the documentation from other hospital foundations in Leon. This surprising absence may perhaps be due to its being acquired in other ways than by direct purchase, such as gifts, exchanges and the like.

The months when the largest numbers of purchases were made were towards the end of the year. This strategy was logical, since by following such a policy the administrators were trying, on the one hand, to stock up the foodstuffs necessary to be in a position to face with some confidence the harsh winter season, and, on the

39 At this period, chocolate should not be seen so much as a foodstuff, but rather as a medicinal product. See Coronas Tejada, L. (1990), El hospital Real de Nuestra Señora de la Misericordia, p. 85.

40 It can be shown, on the basis of products purchased, that the diet provided for patients in the Ponferrada hospital was very similar to what was given to those at Loja and Pamplona. See Coronas Tejada, L. (1990), El hospital Real de Nuestra Señora de la Misericordia,... pp. 83-87. Ramos Martínez, J. (1989), La salud pública y el Hospital General,... pp. 324 et seqq. The commentaries by Eiras Roel and Enríquez Morales upon the feeding of the sick in the Royal Hospital at Saint James of Compostella are ov considerable interest. See EIRAS ROEL, A. and Enríquez Morales, M. I. (1975), "El consumo alimentario en los Colegios Mayores de la Universidad de Santiago y otras colectividades del Antiguo Régimen”, Liceo Franciscano, 82-84, pp. 243-261.

41 So, for example, in May 1796 or June 1800, just two eggs were purchased. In the first instance the administrators specified that they were for use in gargling, in the second that they were for a patient with a digestive ailment. The fact that eggs virtually disappeared from the hospital diet was a reflection of the crisis that the Province of Leon went through from the end of the eighteenth century onwards. This, logically, affected the institution, whose income declined because its tenants could not pay their rents. In the minute book entry for 26 July 1800, it is noted that because of the failure of the crop the tenants are not in a position to pay what is due. A.H.M.P. Folder 26. With respect to what eggs represented in economic fluctuations, see BraudelL, F. (1984), Civilización material, economía y capitalismo (s. XV-XVIII), Madrid: Alianza. Vol. 1, p. 174. With regard to the impact of economic conditions on beneficent actions, see Carasa Soto, P. (1987), Pauperismo y revolución liberal en Burgos (1750-1900), Valladolid: University of Valladolid, p. 378. 
other, to take advantage of seasonal price movements, since at this time many products tended to be cheaper.

\section{Hospital Admissions: Evolution and Seasonal Variation}

To gain an awareness of the variations in occupation levels in the Queen's Hospital, an indirect source must be made use of, the quantities of food served, since neither the register of admissions, nor, failing that, the register of deaths, are available. It is known that the administrators were under an obligation to record such events in the relevant two books, at least from the introduction of the 1788 regulations. However, for the moment it has not proved possible to locate them, despite a careful search through all the documentation generated by the hospital that is to be found in the Ponferrada Municipal Historical Archive.

The problem with using lists of food provided as an alternative indicator lies in the inflation of results. It would seem that in these records all patients remaining in the centre for more than one day, as was quite common, were counted as many

Figure 2. Probable average daily number of patients undergoing treatment in the Queen's Hospital, 1659-1800.

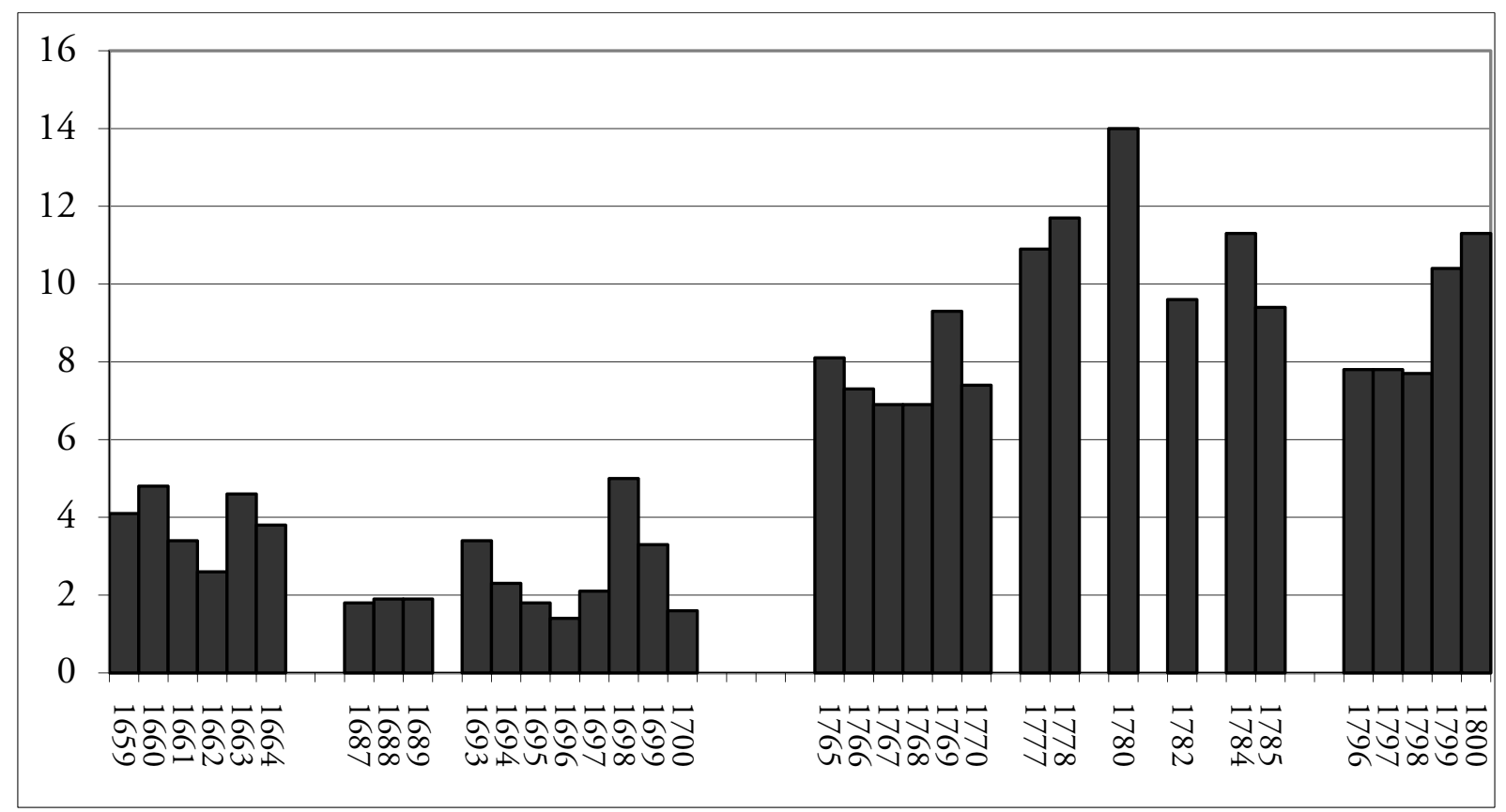


times as the number of days their sicknesses lasted ${ }^{42}$. To correct as far as possible this deficiency in the source, the approach taken here is to calculate the average number of portions served per day, since this indicator comes closer to the likely average of patients in the hospital. So, for instance, in the year 1661, the 1,248 rations provided imply an average daily presence of 3.4 patients.

Taking this index as a basis, it is possible to find evidence, firstly, of the considerable growth in the number of patients treated towards the end of the eighteenth century, in comparison with the previous century (Graph 1). In fact, this figure eventually doubled, going from between two and four rations per day to more than seven. This trend was strongly accentuated during the final quarter of the eighteenth century, a time when there was an acute crisis at a provincial level. It is highly likely, although the sources provide no further data, that this increase in aid continued during the early years of the nineteenth century, as it has proved possible to observe in the neighbouring cities of Astorga and Leon. It should not be forgotten that this growth in assistance provided must have been contributed to significantly by patients not originating in the town. This is a reference not so much to the travellers and pilgrims who were in transit along the Pilgrim's Way, as to inhabitants of nearby rural areas. In times of economic difficulty these latter would make for Ponferrada to seek help from its charitable institutions, as it was the chief town of the district.

The last aspect to be studied is the monthly demand for assistance over the course of the year. For this purpose a time series has been produced, making the appropriate distinction between seventeenth and eighteenth century data (Graph 2). The behaviour patterns observed for the two centuries are very similar, showing a noteworthy rise in aid provided during the months of April, May and June. This peak, more marked in the seventeenth century, is the consequence of the impact on the registers of the movements of seasonal agricultural workers who followed the "French Way" to reach the internal plateau of Spain. Although there are no data on this point, it is likely that among this group there was a considerable representation of people originating in Galicia, a region bordering on the Bierzo district and having a long-established tradition of this sort of transhumance. A second, less pro

42 In the Hospital of Saint Antony the Abbott in the city of Leon and Saint John's Hospital in the city of Astorga, both located in the same Province as the Queen's Hospital, the average hospital stay varied between twenty and thirty days. Martín García, A. and Pérez Álvarez, M. J., (2007), "Hospitalidad y asistencia en la provincia de León a finales del Antiguo Régimen (1728-1896)", Dynamis, 27, pp. 157-185, p. 179; Martín García, A. (2009), "Pobres y enfermos en el León de la Edad Moderna: la asistencia hospitalaria en la ciudad de Astorga”, in Rubio Pérez, L. M. (ed.), Pobreza, marginación y asistencia en la Peninsula Ibérica (siglos XVI-XIX), Leon, University of Leon. 
Figure 3. Average monthly aid provided by the Queen's Hospital, 1659-1800.

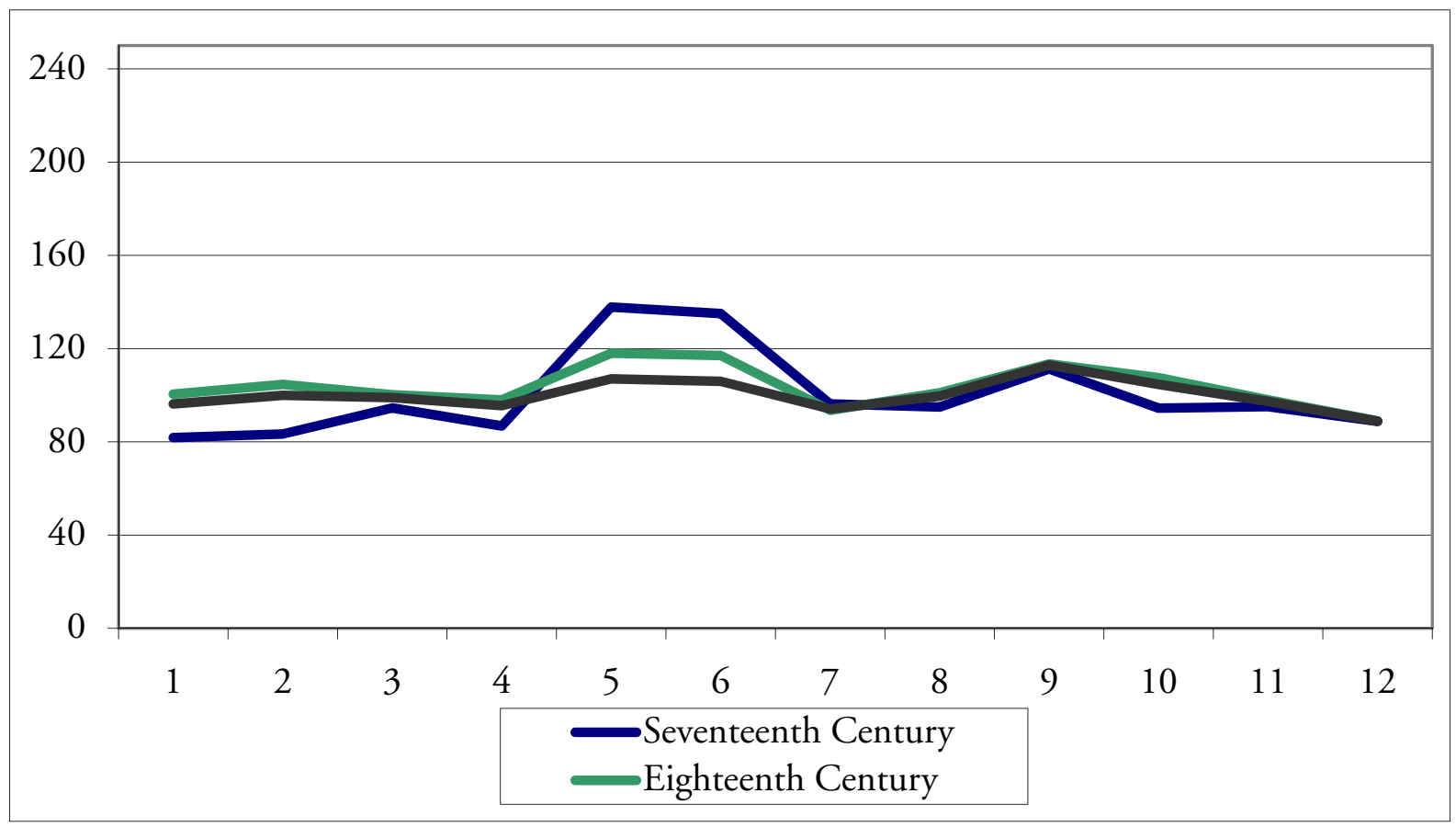

nounced, peak occurred in the month of September, corresponding to the return journeys of such temporary workers to their places of origin.

Apart from these well-defined cycles, the graph shows striking stability in the amount of aid provided. These results correspond to the characteristics of a centre of the modest nature and limited size that is being studied. These characteristics led to a very limited radius of action, practically restricted to the immediate neighbourhood. It should also be remembered that the installations could hold only a very limited number of patients, as the regulations reflect.

\section{Final Conclusions}

A study of the Queen's Hospital in Ponferrada serves to understand the functioning of a typical beneficent centre in the Province of Leon during the Modern Period. Its small dimensions and limited funding put considerable restrictions on its social actions. However, this was far from meaning that it was of no importance in a region rather isolated by its geographical circumstances and having very little urban development.

María José Pérez Alvarez Associate Professor of Modern History at the University of León (Spain). 


\section{Acknowledgement}

This article forms part of the research project entitled "Marginalization and Social Welfare in Leon during the Modern Period", funded by the Education Office of the Regional Government of Castile and León (Ref. LE 0270 A 07). 


\section{References}

Braduel, F. (1984), Civilización material, economía y capitalismo (s. XV-XVIII), Madrid: Alianza. Vol. 1.

Callahan, W. (1978), "Caridad, sociedad y economía en el siglo XVIII", Moneda y Crédito, 146.

Schubert, A. (1984), "Nuevos enfoques sobre la beneficencia en España en el siglo XIX", Studia Zamorensia, 19.

Carasa Soto, P. (1987), Pauperismo y revolución liberal en Burgos (1750-1900), Valladolid: University of Valladolid.

Carasa Soto, P. (1991), Historia de la beneficencia en Castilla y León. Poder y pobreza en la sociedad castellana, Valladolid: University of Valladolid.

Carmona García, J. I. (1979), El sistema de la hospitalidad pública en la Sevilla del Antiguo Régimen, Seville: Seville Provincial Council.

Cavero Domínguez, G. (1987), Peregrinos e indigentes en el Bierzo Medieval (siglos XI-XVI). Hospitales en el Camino de Santiago, Ponferrada: Basílica de la Encina y Asociación de Amigos del Camino de Santiago, pp. 43-52.

Coronas Tejada, L. (1990), El hospital Real de Nuestra Señora de la Misericordia de Loja, Granada: University of Granada.

Eiras Roel, A. and Enríques Morales, M. I. (1975), "El consumo alimentario en los Colegios Mayores de la Universidad de Santiago y otras colectividades del Antiguo Régimen", Liceo Franciscano, 82-84.

García Guerra D. (1983), El hospital Real de Santiago (1499-1804), Corunna: Barrie de la Maza Foundation.

García Guerra, D. (1983), El hospital Real de Santiago... pp. 58-59, and (1978), "La asistencia hospitalaria en la España Moderna: el Hospital Real de Santiago", Estudios de Historia Social, 7, pp. 289-327.

García Hourcade, J. J. (1996), Beneficencia y sanidad en el S. XVIII. El hospital de San Juan de Dios de Murcia, Murcia: University of Murcia.

González Díaz, A. M. (1997), Poder urbano y asistencia social: el hospital de San Hermenegildo de Sevilla (1453-1837), Seville: Seville Provincial Council.

González García, M. "Notas para la historia de Ponferrada”, Bierzo, 1977, pp. 98 104, pp. 98-99.

Henderson, J. (2001) "Healing the Body and Saving the Soul: Hospitals in Renaissance Florence. Renaissance Studies", Journal of the Society for Renaissance Studies, 15 (2), pp. 188-216.

Martín García, A. (2009), "Pobres y enfermos en el León de la Edad Moderna: la asistencia hospitalaria en la ciudad de Astorga". In Rubio Pérez, L. M. (ed.), Pobreza, marginación y asistencia en la Peninsula Ibérica (siglos XVI-XIX), Leon, University of Leon. 
Martín García, A. and Pérez Álvarez, M. J., (2007), "Hospitalidad y asistencia en la provincia de León a finales del Antiguo Régimen (1728-1896)”, Dynamis, 27.

Ramos Martínez, J. (1989), La salud pública y el Hospital General de la ciudad de Pamplona en el Antiguo Régimen (1700 a 1815), Pamplona: Regional Government of Navarre.

Valenzuela Candelario, J. (2002), "Hospitales y Beneficencia. Historias de hospitales". Revista de Trabajo Social y Salud, 43. 